Revista de Biología Marina y Oceanografía

Vol. 50, №3: 597-602, diciembre 2015

DOI: 10.4067/S0718-19572015000400018

ReseArch Note

\title{
First confirmed report of Hawksbill Sea Turtle Eretmochelys imbricata in nearshore waters of Easter Island (Rapa Nui)
}

\author{
Primer reporte confirmado de Tortuga Carey Eretmochelys imbricata \\ en aguas costeras de Isla de Pascua (Rapa Nui)

\section{Rocío Álvarez-Varas ${ }^{1}$, Marcelo Flores ${ }^{2}$, Diego Demangel ${ }^{3}$, Michel García ${ }^{4}$ and Nicole Sallaberry-Pincheira ${ }^{5}$}

\begin{abstract}
${ }^{1}$ ONG Qarapara Tortugas Marinas Chile, Las Flores Oriente 2725, Peñalolén, Santiago, Chile. ralvarez03@gmail.com ${ }^{2}$ Departamento de Ecología y Biodiversidad, Facultad de Ecología y Recursos Naturales, Universidad Andres Bello, República 470, Piso 3, Santiago, Chile

${ }^{3}$ Salvador Sur 1039, Villa Olímpica, Nuñoa, Santiago, Chile

${ }^{4}$ ORCA Diving Center, Hanga Roa, Easter Island, Chile

${ }^{5}$ Centro de Sustentabilidad y Escuela de Medicina Veterinaria, Facultad de Ecología y Recursos Naturales, Universidad Andres Bello, República 440, Santiago, Chile
\end{abstract}

\begin{abstract}
The hawksbill turtle (Eretmochelys imbricata; Critically Endangered) has a circumtropical distribution. In Polynesia it inhabits the waters of a great number of islands; however, up to date there are no official records for Easter Island. We document the first report of E. imbricata in Easter Island and Chile based on underwater photographs and examination of one individual. The confirmation of the presence of hawksbills extends the known distribution range for the species, increases the number of sea turtle species recorded for Chile, and highlights the need for further research on potential threats to the species and the importance of Rapa Nui as developmental and foraging habitat for hawksbills.
\end{abstract}

Key words: Hawksbill Turtle, Easter Island, Chile, Polynesia

\section{INTRODUCTION}

The hawksbill sea turtle Eretmochelys imbricata (Linnaeus, 1766) has a circumglobal distribution in tropical and subtropical waters throughout the Atlantic, Indian, and Pacific Oceans. Its worldwide population declined severely during the last century, mainly due to intense exploitation of eggs and turtles for food and tortoiseshell (Mortimer \& Donnelly 2008, Gaos et al. 2010). Unfortunately, other threats have also increased over this period for this species, such as loss of nesting beaches and coral reef foraging habitats, and increased incidental capture and marine pollution. All these factors have resulted in the hawksbill turtle being categorized as Critically Endangered by the IUCN Red List of Threatened Species (Mortimer \& Donnelly 2008).

In the Pacific Ocean E. imbricata ranges from the coast of Baja California to Peru (National Marine Fisheries Service \& U.S Fish and Wildlife Service 1998, Quiñones et al. 2011, NOAA 2014) and is found in several islands of the Indo-Pacific Region (Woodrom 2010). In Polynesia the species is present in waters of a great number of islands including Hawaii, Cook Islands, French Polynesia; Samoa, Tokelau, Tonga, Niue, and Pitcairns Islands (Witzell \& Banner 1980, Balazs 1983, Woodrom 2010). However, to date although there are anecdotal reports of hawksbill turtles in Easter Island waters, there have been no confirmed records of this species for the island.

Easter Island $\left(27.0724^{\circ} \mathrm{S} ; 109.2157^{\circ} \mathrm{W}\right)$ is in to the most easterly corner of the Polynesian triangle and is part of Chilean territory (Fig. 1). Its culture, isolated location and archaeological heritage attract more than 40,000 visitors per year, with tourism being the most important economic activity, followed by fishing (DIRPLAN 2011', INE 2012). In 2012 Álvarez-Varas et al. $2012^{2}$ found that fishing, marine pollution and recreational activities (diving and

${ }^{1}$ DIRPLAN. 2011. Minuta plan especial Isla de Pascua. Santiago. DIRPLAN, Departamento de Planificación, Ministerio de Obras Públicas, Santiago de Chile. <http://www.dirplan.cl/planes/especiales/Paginas/DetallePlanesespeciales.aspx?item=22> ${ }^{2}$ Álvarez-Varas R, K Skamiotis, P Stowhas \& C Bonacic. 2012. Rapid assessment of sea turtles conservation in Easter Island (Rapa Nui) in the South Pacific. XXXII Annual Symposium on Sea Turtle Biology and Conservation, Huatulco-Mexico, 11-16 March 2012. 


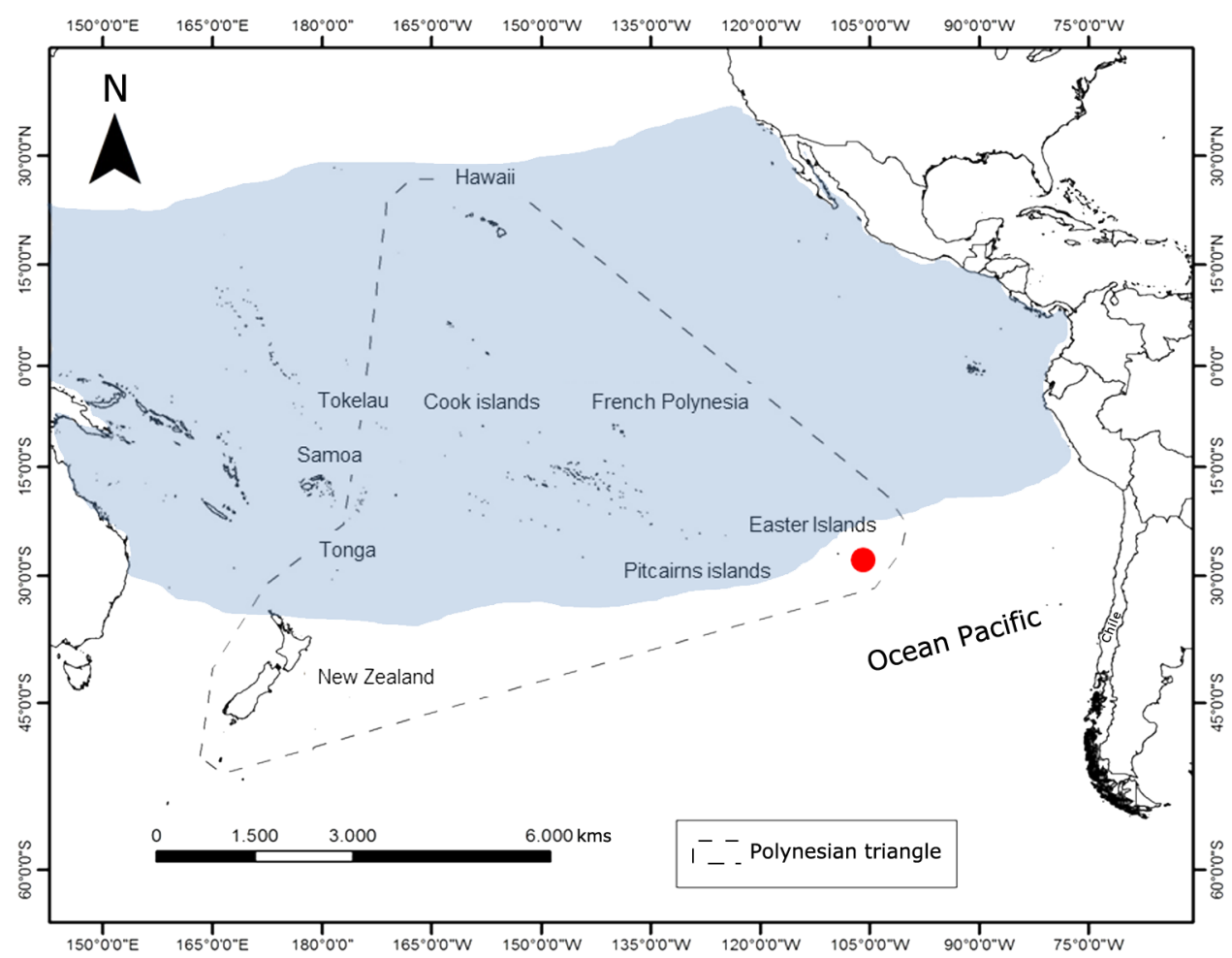

Figure 1. Polynesian triangle (dotted line) and the approximate distribution range of Eretmochelys imbricata (blue) in the Pacific Ocean. Red point indicates new report of hawksbill sea turtle. Distribution based on NOAA 2014 data and Daniel Godoy personal communication (New Zealand) / Triángulo Polinésico (línea punteada) y rango de distribución aproximado de Eretmochelys imbricata (azul) en el Océano Pacífico. El punto rojo indica el nuevo reporte de tortuga carey. Distribución basada en datos de NOAA 2014 y comunicación personal con Daniel Godoy (Nueva Zelanda)

snorkelling, among others) represented major threats to sea turtles in the island. In the present study, it was documented for the first time the presence of E. imbricata in Easter Island, through underwater photographs and examination of one individual.

\section{MATERIALS AND METHODS}

On August 14, 2013 at 15:49 pm at Hanga Roa bay (southwest portion; $27.0902^{\circ} \mathrm{S} ; 109.2632^{\circ} \mathrm{W}$ ), during diving activities, a hawksbill turtle was observed and photographed using a digital camera swimming in a coral reef (Canon ${ }^{\circledR}$ model Powershot G-15; Fig. 2). Approximately one year later on October 3,2014, at 15:30 pm, also at Hanga Roa $\left(27.0850^{\circ} \mathrm{S} ; 109.2604^{\circ} \mathrm{W}\right)$, another individual was observed floating on the surface and was taken to shore by a surfer for examination. The turtle was assisted in the island by a local veterinarian and the Fisheries National Service of the Chilean Government (SERNAPESCA). Later, the turtle was transported to continental Chile, where it was assisted by veterinarians of the Qarapara Tortugas Marinas Chile NGO and Universidad Santo Tomás. In October 26, 2014, the turtle was found dead, and according to the necropsy, the signs observed were consistent with chronic renal failure and intestinal obstruction.

The shape of the carapace (oval with a strongly serrated posterior margin and thick overlapping scutes), number of scutes ( 4 pairs of costal scutes and 5 central scutes), and the shape and number of scutes of the head (straight bird-like beak with 2 pairs of prefrontal scales) (Pritchard \& Mortimer 1999), allowed us to definitively identify the species (Figs. 2 and 3). Age stage was defined according to Snover et al. (2013), who used skeletochronology in Hawaiian hawksbill turtles and determined the age of maturity as occurring between 17 to 22 years at a size of $78.6 \mathrm{~cm}$ of straight carapace length notch to tip (SCLn-t). In the case of the 2014 turtle, the sex was determined through direct gonad examination during the necropsy of the individual. 


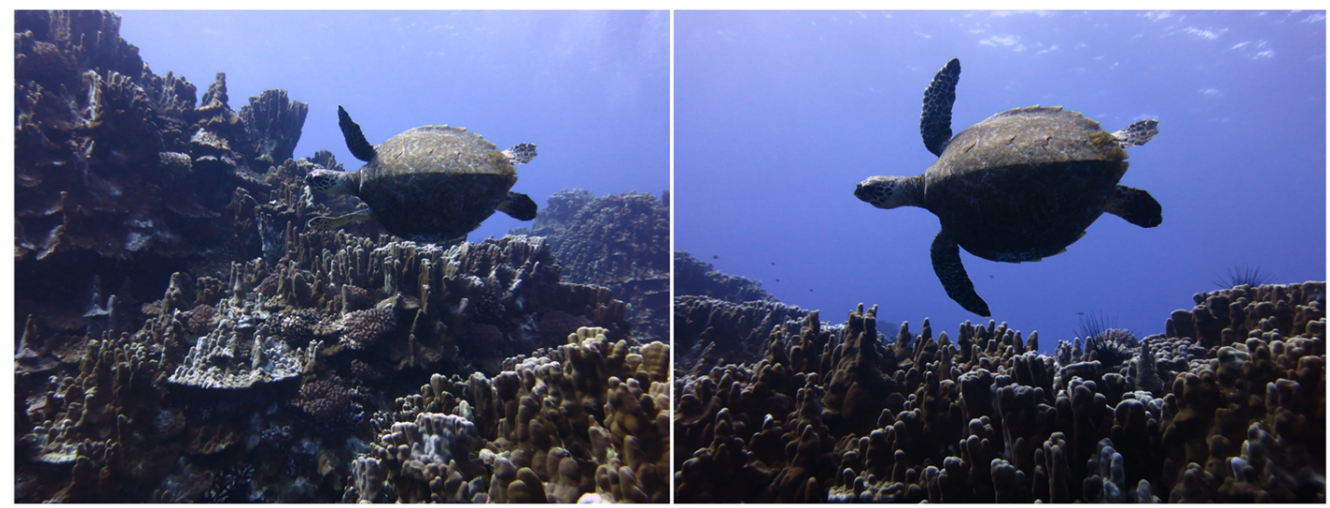

Figure 2. Individual of Eretmochelys imbricata swimming in coral reef $\mathbf{2 0 0} \mathbf{m}$ west of Hanga Roa bay, Easter Island / Individuo de Eretmochelys imbricata nadando en el arrecife de coral a $200 \mathrm{~m}$ al oeste de la bahía Hanga Roa, Isla de Pascua

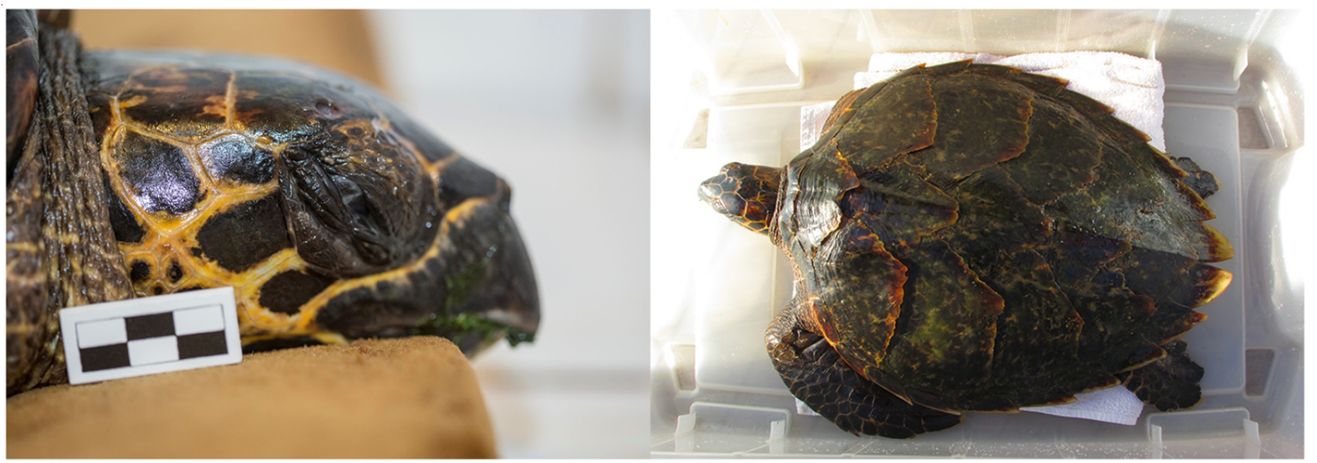

Figure 3. Juvenile Eretmochelys imbricata found floating on water surface. In the left photo a standard scale of $3 \mathrm{~cm}$ divided in $1 \mathrm{~cm}$ rectangles was used. Right photo shows the absence of its anterior right flipper and a marked indentation in the rear portion of the first central scute / Juvenil de Eretmochelys imbricata encontrado flotando en la superficie del agua. En la foto de la izquierda se utilizó una regla estándar de $3 \mathrm{~cm}$ dividida en $1 \mathrm{~cm}$. La foto de la derecha muestra la ausencia de su aleta anterior derecha y una marcada hendidura en la porción posterior del primer escudo central

The 2014 individual was differentiated from the 2013 individual due to the absence of its anterior right flipper with well-healed tissue on the stump and the shape of the first central scute, which presented a marked indentation at its rear portion, probably caused by a lacerating wound (Figs. 2 and 3). Measurements of this individual were obtained based on Bolten (1999). The straight measurements of the 2014 turtle were obtained with a digital caliper (Mitutoyo model 700-128) with a $0.5 \mathrm{~mm}$ error and the curved measurements were determined with metric measuring tape. The weight was obtained with a balance (model PHSO40) with an error of $\pm 40 \mathrm{~g}$.

\section{RESULTS AND DISCUSSION}

Although the hawksbill sighted in 2013 (Fig. 2) could not be caught for measurement, based on photographs and the author's experience, we estimated a carapace length corresponding to a juvenile individual. The body measurements of the 2014 turtle were obtained the first day of examination, and were as follows: Minimum curved carapace length $($ CCLmin $)=44 \mathrm{~cm}$; Curved carapace length notch to tip $(C C L n-t)=49 \mathrm{~cm}$; Curved carapace width $(\mathrm{CCW})=42.8 \mathrm{~cm}$; Straight carapace length notch to tip $(\mathrm{SCLn}-\mathrm{t})=47 \mathrm{~cm}$; Straight carapace width $(\mathrm{SCW})=37.9$ $\mathrm{cm}$; Plastron length $(\mathrm{PL})=34.4 \mathrm{~cm}$; Plastron width $(\mathrm{PW})=$ $32.6 \mathrm{~cm}$; Head length $(\mathrm{HL})=13.22 \mathrm{~cm}$; Head width $(\mathrm{HD})=$ $7.38 \mathrm{~cm}$; Total tail length $(\mathrm{TL})=5.44 \mathrm{~cm}$; and Post-cloacal tail length $(\mathrm{PTL})=4.83 \mathrm{~cm}$ ( see Fig. 3). It weighed $9.65 \mathrm{~kg}$. In this case, the SCLn-t indicated that this turtles was a juvenile hawksbill turtle. During the necropsy, its sex was classified as female by examination of the gonads. 
In general, data on the sea turtles of Easter Island are uncommon in the literature. At present, although 4 species have been described for Chilean continental waters (Caretta caretta, Chelonia mydas, Dermochelys coriacea and Lepidochelys olivacea; Ponce et al. 2013 ${ }^{3}$ ), only 2 of these ( $C$. mydas and D. coriacea) have been documented for Rapa Nui (Zárate 2012). In 1966, Donoso-Barros mentioned the presence of Eretmochelys imbricata (Linnaeus, 1766) in Easter Island, based on a description presented by Garman (1908), who recognized the presence of this species with the synonym of Eretmochelys squamosa. However, Garman's (1908) statement: 'To give an approximately complete idea of Herpetology of Easter Island it is necessary to consider and introduce provisionally into our list of species a number of marine tortoise and a sea serpent, which range throughout Polynesia and the tropical and the temperate portions of the Pacific and the Indian oceans, but which have not yet been taken or known directly from the island by the scientist... The tortoises, of which our knowledge depends wholly upon tradition or other evidence of the natives, cannot be satisfactorily identified' suggests that he did not specifically identify the hawksbills and that Donoso-Barros's (1966) report of the hawksbill turtle in Easter Island was based on erroneous data (Garman's statement). Similarly, Yañez (1951) and later Witzell (1983) also reported the presence of hawksbill turtles in the island based on Garman's report. In 1971, Harrison mentioned the occurrence of at least 3 sea turtle species in the island (possibly 4), but he did not specify which species were present. Later, Pritchard (1981) mentioned the presence of hawksbills in Rapa Nui based on a letter written by Tom Harrison (March 1971), who indicated the occurrence of at least green, ridley and hawksbill turtles in the island. Nevertheless, Pritchard (1981) did not specify whether these species were observed and identified by Harrison or by others, and he did not provide photographic evidence of the sea turtles present in the island. Finally, in 1997 in a report of the National Forest Corporation of Chile (CONAF 1997) the sporadic presence of E. imbricata and $C$. mydas in the island was mentioned; however, the authors did not provided further information on how they had determined this.
Several authors have described the importance of coral reef ecosystems as foraging grounds and developmental areas for hawksbill turtles (e.g., Musick \& Limpus 1996, León \& Bjorndal 2002, Troeng et al. 2005). These types of habitats support populations of juvenile and adults hawksbills foraging mainly on reef-associated sponges (León \& Bjorndal 2002) throughout the year; with adults sometimes travelling large distances from their nesting areas (Bowen et al. 1996, Troeng et al. 2005, Vilaca et al. 2013). Thus, coral reefs are critical for hawksbill turtle conservation.

Easter Island provides extensive coral habitats, where $53 \%$ of the bottom can be covered by live coral (National Geographic Society et al. 20114). To date 13 species of coral (Glynn et al. 2007) and at least 11 sponge species have been recognized in the island, the latter being highly abundant in certain areas (Di Salvo et al. 1988, Glynn et al. 2003). Although we could not obtain the measurements of the 2013 turtle, in both cases we estimated that they were juvenile individuals. The presence of juveniles of $E$. imbricata suggests that Easter Island could be an important foraging ground for hawksbill turtles in the middle of the Pacific Ocean, and its coral reef ecosystems play an important role in their development. Nevertheless, further research to determine their abundance, distribution and their diet in Rapa Nui's reefs, as well as genetic analyses and satellite tracking to determine their origin and movements would be needed, thus evaluating the importance of Rapa Nui as developmental habitats for hawksbill turtles.

Easter Island is one of the main touristic centers of Chile, reaching up to more than 40,000 visitors from around the world in 2012 with an increase of $19.9 \%$ since 2011 (INE 2012). This marked increase of tourism in the island intensifies the demand on marine natural resources and increases the development of recreational activities related to the sea. Thus, threats to marine life including increased fishing effort, marine pollution, habitat degradation, boat collisions, bycatch, among other threats, are probably becoming more significant. Although Álvarez-Varas et al. $(2012)^{2}$ found that nowadays the consumption of sea turtles is rarely practiced by the Rapa

\footnotetext{
${ }^{3}$ Ponce F, J Azocar \& M Donoso. 2013. Convención Interamericana para la Protección y Conservación de las Tortugas Marinas Chile. Informe Anual 2013. Subsecretaría de Pesca y Acuicultura, Chile. <http://www.iacseaturtle.org/docs/informes-anuales/ 2013/Informe-Anual-2013-Chile.pdf>

${ }^{4}$ National Geographic Society, Oceana Chile \& Armada de Chile. 2011. Expedición a la Isla de Pascua y Salas y Gómez. Informe Científico, Febrero-Marzo 2011. <http://oceana.org/sites/default/files/o/uploads/_sao/InformecientificoExpedicionaSalasy GomezelsladePascuaFINAL_baja.pdf>
} 
Nui community, there is an as yet unquantified demand for sea turtle meat by restaurants in the island. Increased tourism could therefore represent a new threat for sea turtles in Easter Island. Finally, all of these potential threats towards hawksbill turtles in Rapa Nui should be evaluated to define future protection plans that include outreach and educational activities with the local people.

The documented presence of E. imbricata in Easter Island extends the known distribution range for this species in the Polynesian Region, and also increases the number of sea turtle species recorded in Chile. As the only site for hawksbill sea turtles in Chile, the need to begin research on this critically endangered species and its habitats in Rapa Nui is highlighted. This information will allow us to understand the role of the island as a developmental and feeding area for hawksbills and formulate appropriate management and conservation strategies, especially considering the threats from growing tourism and increased fishing effort in Easter Island in recent years.

\section{ACKNOWLedgments}

We thank to Camila González, Alejandro Bugueño, Rebeca Tepano, Anita Espinoza, Maria José Brain, Orca's team and Fisheries National Service of Chilean Government (SERNAPESCA) for their contribution during rescue and rehabilitation activities in Easter island. We would also like to thank Robert Petitpas for the map and Alejandro Fallabrino for his comments and contacts that were invaluable for the correct identification of the individuals.

\section{LITERATURE CITED}

Balazs GH. 1983. Sea turtles and their traditional usage in Tokelau. Atoll Research Bulletin 279: 1-30.

Bolten AB. 1999. Techniques for measuring sea turtles. In: Eckert K, K Bjorndal, F Abreu-Grobois \& M Donnelly (eds). Research and management techniques for the conservation of sea turtles, pp. 110-114. IUCN/SSC Marine Turtles Specialist Group, Pennsylvania.

Bowen BW, AL Bass, A García-Rodríguez, CE Diez, R van Dam, A Bolten, KA Bjorndal, MM Miyamoto \& RJ Ferl. 1996. Origin of hawksbill turtles in a Caribbean feeding area as indicated by genetic markers. Ecological Applications 6(2): 566-572.

CONAF. 1997. Plan de Manejo Parque Nacional Rapa Nui, 162 pp. Ministerio de Agricultura, Corporación Nacional Forestal, Unidad de Gestión Patrimonio Silvestre, Santiago de Chile. <http://www.conaf.cl/wp-content/files_mf/ 1382466339PNRapaNui.pdf>
Di Salvo L, J Randall \& A Cea. 1988. Ecological reconnaisance of the Easter Island sublitoral marine environment. National Geographic Research 4(4): 451-473.

Donoso-Barros R. 1966. Reptiles de Chile, 458 pp. Ediciones de la Universidad de Chile, Santiago.

Gaos A, FA Abreu-Grobois, J Alfaro-Shigueto, D Amorocho, R Arauz, A Baquero, R Briseño, D Chacon, C Dueñas, C Hasbun, M Liles, G Mariona, C Muccio, JP Muñoz, WJ Nichols, M Peña, JA Seminoff, M Vasquez, J Urteaga, B Wallace, IL Yañez \& P Zarate. 2010. Signs of hope in the Eastern Pacific: International collaboration reveals encouraging status for the severely depleted population of hawksbill turtles Eretmochelys imbricata. Oryx 44: 595-601.

Garman S. 1908. The reptiles of Easter Island (Expedition to the Eastern Tropical Pacific 1904-1905). Bulletin of the Museum of Comparative Zoology 53(1): 1-14.

Glynn PW, GM Wellington, EA Wieters \& SA Navarrete. 2003. Reef-building coral communities of Easter Island (Rapa Nui), Chile. In: Cortés J (ed). Latin American coral reefs, pp. 473-494. Elsevier Science, Amsterdam.

Glynn PW, GM Wellington, B Riegl, DB Olson, E Borneman \& EA Wieters. 2007. Diversity and biogeography of the scleractinian coral fauna of Easter Island (Rapa Nui). Pacific Science 61(1): 67-90.

Harrison T. 1971. Easter Island: A last outpost. Oryx 11(2-3): 111-116.

INE. 2012. Turismo, Informe anual 2012. Instituto Nacional de Estadísticas, Subdirección de Operaciones, Subdepartamento Estadísticas Coyunturales de Comercio y Servicios, Santiago de Chile. <www.ine.cl/canales/menu/publicaciones/ calendario_de_publicaciones/pdf/informe _ anual _ turismo _2012.pdf>

León Y \& K Bjorndal. 2002. Selective feeding in the hawksbill turtle, an important predator in coral reef ecosystems. Marine Ecology Progress Series 245: 249-258.

Mortimer JA \& M Donnelly. 2008. Eretmochelys imbricata. In: IUCN Red list of threatened species. Version 2010.1. International Union for Conservation of Nature and Natural Resources, IUCN. <www.iucnredlist.org>

Musick JA \& CJ Limpus. 1996. Habitat utilization and migration in juvenile sea turtles. In: Lutz PL \& JA Musick (eds). The biology of sea turtles, pp. 137-155. CRC Press, Boca Raton.

National Marine Fisheries Service \& US Fish and Wildlife Service. 1998. Recovery plan for U.S Pacific populations of the hawksbill turtle (Eretmochelys imbricata). National Marine Fisheries Service, Silver Springs. < www.nmfs.noaa.gov/pr/pdfs/recovery/turtle _ hawksbill _ pacific.pdf>

NOAA. 2014. Fisheries Home Protected Resources Species. Sea Turtles Hawksbill Turtle (Eretmochelys imbricata). NOAA Fisheries, National Marine Fisheries Service, Silver Spring. <www.nmfs.noaa.gov/pr/species/turtles/hawksbill.htm>. 
Pritchard PCH. 1981. Marine turtles of the South Pacific. In: Bjorndal K (ed). Biology and conservation of Sea Turtles, pp. 253-262. Proceedings of the World Conference on Sea Turtle Conservation held at the U.S. State Department Building, Washington.

Pritchard PCH \& JA Mortimer. 1999. Taxonomy, external morphology, and species identification. In: Eckert K, K Bjorndal, F Abreu-Grobois \& M Donnelly (eds). Research and management techniques for the conservation of sea turtles, pp. 21-40. IUCN/SSC Marine Turtles Specialist Group, Pennsylvania.

Quiñones J, J Zeballos, S Quispe \& L Delgado. 2011. Southernmost records of hawksbill turtles along the east pacific coast of South America. Marine Turtle Newsletter 130: $16-19$.

Snover ML, GH Balazs, SKK Murakawa, SK Hargrove, MR Rice \& WA Seitz. 2013. Age and growth rates of Hawaiian hawksbill turtles (Eretmochelys imbricata) using skeletochronology. Marine Biology 160: 37-46.

Troeng S, PH Dutton \& D Evans. 2005. Migration of hawksbill turtles Eretmochelys imbricata from Tortuguero, Costa Rica. Ecography 28: 394-402.
Vilaca ST, P Lara-Ruiz, MA Marcovaldi, LS Soares \& FR Santos. 2013. Population origin and historical demography in hawksbill (Eretmochelys imbricata) feeding and nesting aggregates from Brazil. Journal of Experimental Marine Biology and Ecology 446: 334-344.

Witzell WN. 1983. Synopsis of biological data on the hawksbill turtle, Eretmochelys imbricata (Linnaeus, 1766), FAO Fisheries Synopsis 137: 1-78. <http://www.fao.org/docrep/ 017/ap937e/ap937e.pdf>

Witzell WN \& AC Banner. 1980. The hawksbill turtle in Western Samoa. Bulletin of Marine Science 30(3): 571-579.

Woodrom R. 2010. Forbidden sea turtles: Traditional laws pertaining to sea turtle consumption in Polynesia (including the Polynesian outliers). Conservation and Society 8: 84-97.

Yañez A. 1951. Vertebrados marinos chilenos. III. Reptiles. Revista de Biología Marina 3: 1-18.

Zárate P. 2012. Offshore oasis: Ecology of sea turtles at oceanic islands of the eastern Pacific. In: Seminoff. JA \& BP Wallace (eds). Sea turtles of the eastern Pacific: Advances in research and conservation, pp. 64-87. The University of Arizona Press. Tucson. 